\title{
IN SITU HYBRIDIZATION WITH cDNA PROBES: ITS APPLICATION TO THE DETECTION OF mRNAS FOR MYELIN PROTEINS (PLP AND MBP) IN MOUSE BRAIN SECTIONS
}

\author{
Chiyo SHIOTA and Katsuhiko MIKOSHIBA
}

\author{
Division of Regulation of Macromolecular Function, Institute for Protein Research, \\ Osaka University, Osaka 565
}

\begin{abstract}
In situ hybridization is a method for identifying specific DNA or RNA sequences in cells or tissues. It was originally developed for the detection of specific DNA sequences in chromosomes $(2,6)$, then extended to the detection of specific endogenous mRNA in cells (5). Various kinds of nucleotide sequences, such as complementary DNA (cDNA), antisense RNA and synthetic oligonucleotide that have been labeled with radioactive or otherwise detectable molecules, could be acceptable as probes for in situ RNA hybridization, as well as Northern hybridization. Among these probes, the radioactive cDNA probe is the most widely used for in situ hybridization. With a rapidly increasing number of cDNAs corresponding to molecules of interest, in situ hybridization has been extensively used in various fields such as neurobiology, endocrinology, developmental biology, etc. The detection of mRNAs for myelin basic protein (MBP) and myelin proteolipid protein (PLP) $(7,12,13)$ is a good example of successful application of in situ hybridization. Here we describe our evaluation of some technical conditions which are generally used in in situ hybridization. We also show the distribution of MBP and PLP mRNAs in the mouse brain sections revealed by the relatively simple but effective method of in situ hybridization.
\end{abstract}

\section{MATERIALS AND METHODS}

Animals and tissue preparations: Eighteen- and 30-day-old ICR mice were anesthetized with sodium pentobarbital $(150 \mathrm{mg} / \mathrm{kg}$, i.p. $)$ and perfused transcardially with ice-cold $4 \%$ paraformaldehyde in $0.1 \mathrm{M}$ phosphate buffer, $\mathrm{pH} 7.2$ for 15$30 \mathrm{~min}$. Thereafter, the brains were removed, post-fixed by immersion in the same solution at $4^{\circ} \mathrm{C}$ for $2-3 \mathrm{hr}$, then dehydrated through graded ethanol solutions, cleared with chloroform, and embedded in paraffin. Serial sections $6 \mu \mathrm{m}$ thick were cut by the conventional technique. For frozen sections, the brains were rapidly removed after decapitation, and frozen in liquid $\mathrm{N}_{2}$. Sections $10 \mu \mathrm{m}$ thick were cut in a cryostat at $-20^{\circ} \mathrm{C}$, thawmounted onto glass slides, and fixed in cold $4 \%$ paraformaldehyde in $0.1 \mathrm{M}$ phosphate buffer, $\mathrm{pH} 7.2$, for $5 \mathrm{~min}$. Then the sections were rinsed with phosphate buffered saline (PBS) and air dried. The paraffin sections were stored at room temperature for up to a year, whereas the frozen sections were stored at $-20^{\circ} \mathrm{C}$ for up to two weeks. The glass slides used were previously treated with gelatin-chromic alum solution (3).

Correspondence: Katsuhiko Mikoshiba, Division of Regulation of Macromolecular Function, Institute for Protein research, Osaka University, 3-2 Yamadaoka, Suita-shi, Osaka 565. Tel.: 06-8775111 (ext. 3866). 
Probe synthesis: Rat PLP cDNA clone (p27)(11) was a gift from Dr. Sutcliffe and mouse MBP cDNA was cloned by Kimura et al (8). These cDNAs were labeled with either deoxycytidine $5^{\prime}-\left[\alpha{ }^{32} \mathrm{P}\right]$ triphosphate or deoxycytidine $5^{\prime}-\left[\left[{ }^{35} \mathrm{~S}\right]\right.$ thio $]$ triphosphate by the random-primed DNA-labeling method using a commercially available kit (Boehringer Mannheim). The resulting probes were 50-150 bases in length and 6$8 \times 10^{8} \mathrm{dpm} / \mu \mathrm{g}$ of DNA in specific activity.

In situ hybridization: In situ hybridization was carried out essentially as described by Hafen et al (4). Immediately before use, paraffin sections were deparaffined with xylene, rehydrated through graded ethanol solutions and rinsed in PBS. On the other hand, frozen sections were brought to room temperature and then rinsed in PBS. The sections were treated with $0.2 \mathrm{~N} \mathrm{HCl}$ for $20 \mathrm{~min}$ at room temperature, rinsed in PBS again and incubated in $2 \times \mathrm{SSC}(1 \times \mathrm{SSC}$ : $150 \mathrm{mM} \mathrm{NaCl}, 15 \mathrm{mM} \mathrm{Na}$-citrate $)$ for 30 min at $70^{\circ} \mathrm{C}$. After a brief wash in PBS, the slides were dehydrated through graded ethanol solutions (70, 95 and 100\%) containing $300 \mathrm{mM}$ ammonium acetate, and air-dried. For proteinase digestion, the sections were incubated in proteinase $\mathrm{K}$ solution $\left(2 \mu \mathrm{g} / \mathrm{ml}\right.$ proteinase $\mathrm{K}, 10 \mathrm{mM}$ Tris- $\mathrm{HCl}$ buffer, $\mathrm{pH} 7.0,2 \mathrm{mM} \mathrm{CaCl}_{2}$ ) for $15 \mathrm{~min}$ at $37^{\circ} \mathrm{C}$ after $2 \times \mathrm{SSC}$ treatment, then treated sequentially with $2 \mathrm{mg} / \mathrm{ml}$ glycine in PBS and 4\% paraformaldehyde in $0.1 \mathrm{M}$ phosphate buffer, for $5 \mathrm{~min}$ each. The sections were prehybridized for $3-4 \mathrm{hr}$ at $37^{\circ} \mathrm{C}$ by covering them with hybridization buffer. The hybridization buffer consisted of $50 \%$ formamide, $10 \%$ dextran sulfate, $0.8 \mathrm{M} \mathrm{NaCl}, 7 \mathrm{mM}$ Tris-HCl, $\mathrm{pH} 7.4,1.3 \times$ Denhardt's solution $(1 \times$ Denhardt's solution: $0.02 \%$ bovine serum albumin, $0.02 \%$ polyvinylpyrrolidone, $0.02 \%$ Ficoll), $0.6 \mathrm{mM}$ EDTA, $0.03 \%$ herring sperm DNA and $0.03 \%$ yeast tRNA. To end prehybridization, the hybridization buffer was drained off. Then the sections were hybridized for $14-16 \mathrm{hr}$ at $37^{\circ} \mathrm{C}$ under glass coverslips in $50 \mu \mathrm{l}$ of probe solution $(1 \times$ $10^{4} \mathrm{cpm} / \mu \mathrm{l}$ of ${ }^{32} \mathrm{P}$-or ${ }^{35} \mathrm{~S}$-labeled cDNA probes in hybridization buffer). The probe solution was applied directly to dry sections where prehybridization was omitted. In the case of hybridization using ${ }^{35} \mathrm{~S}$-labeled probe, $10 \mathrm{mM}$ (L)-methionine and $20 \mathrm{mM}$ 2-mercaptoethanol were added to the hybridization buffer. During prehybridization and hybridization, the slides were placed in a moist chamber to prevent the sections from drying. Then the coverslips were removed and the slides were washed for $3 \mathrm{hr}$ in $2 \times \mathrm{SSC}$ at 37,42 or $50^{\circ} \mathrm{C}$ and subsequently $0.2 \times \mathrm{SSC}$ at room temperature for $15 \mathrm{~min}$. The washing solution contained $1 \%$ sodium thiosulfate and $14 \mathrm{mM} 2$-mercaptoethanol when a ${ }^{35} \mathrm{~S}$-labeled probe was used. Finally, the slides were dehydrated through graded ethanol solutions and air-dried.

Hybridization signals were detected by autoradiography using either X-ray film or emulsion (Kodak NTB-2, in a 1:1 mixture with distilled water).

Immunohistochemistry: For immunological detection of MBP, rabbit antiserum against chick MBP was used. The characteristics of the antiserum have been described elsewhere $(9,10)$. Following incubation in primary antiserum, the sections were processed by the avidin-biotin-peroxidase method (Vectastain ABC kit, Vector Labs.). As the chromogen, 3, 3'-diaminobenzidine tetrahydrochloride was used.

\section{RESULTS}

We first tested the effect of proteinase digestion of sections on the efficacy of hybridization with MBP cDNA probe. Since oligodendrocytes, myelin forming cells 

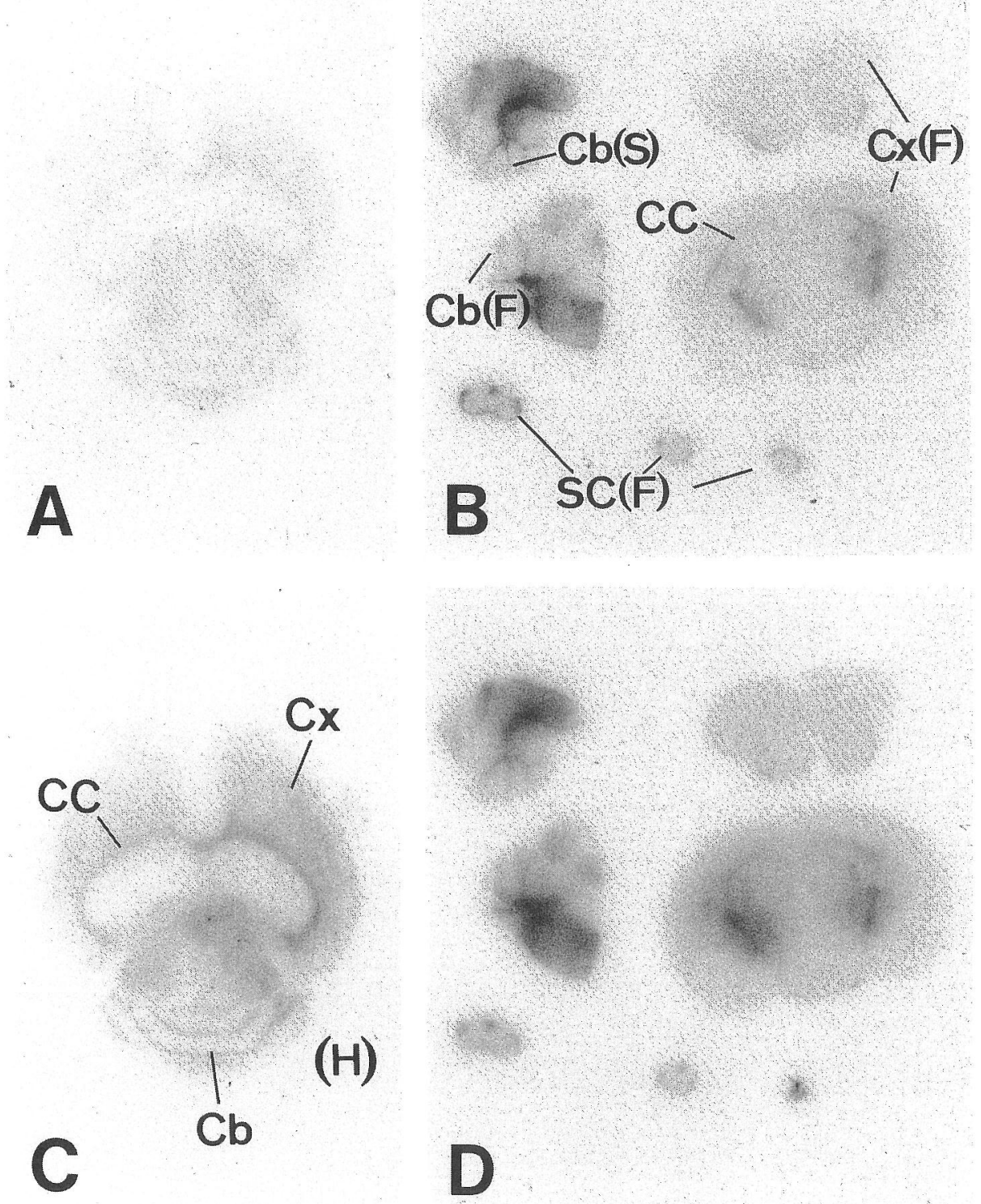

FIGs. 1. A-D. The effect of proteinase $\mathrm{K}$ on in situ hybridization. The effect of proteinase $\mathrm{K}$ was tested on frozen ( $A$ and $C$ ) and paraffin (B and D) sections prepared from the 18-day-old mouse brains. The proteinase $\mathrm{K}(2 \mu \mathrm{g} / \mathrm{ml})$ treatment was performed for $15 \mathrm{~min}$ at $37^{\circ} \mathrm{C}$. Together with the non-treated sections ( $A$ and $B$ ), the treated sections ( $C$ and $D$ ) were hybridized with a ${ }^{32} \mathrm{P}$-labeled MBP cDNA probe and exposed to X-ray film. Cb, cerebellum; $\mathrm{Cx}$, cerebral cortex; $\mathrm{CC}$, corpus callosum; SC, spinal cord. F, H, S in parentheses indicate the orientation of sections; frontal, horizontal and sagittal, respectively. 
in the central nervous system, are abundant in the region of white matter, we could determine the efficacy of hybridization by means of the intensity of radioactivity in the white matter and its ratio to that in gray matter. When the treatment with proteinase $\mathrm{K}$ was omitted, hybridization signals were weak in the frozen sections, but they were relatively strong in the paraffin sections (Figs. 1A, B). In the frozen sections, the treatment with proteinase $\mathrm{K}$ facilitated the hybridization (Fig. 1C). But the effect of the treatment was not greater in the paraffin sections than the frozen ones (Fig. 1D). Fur-

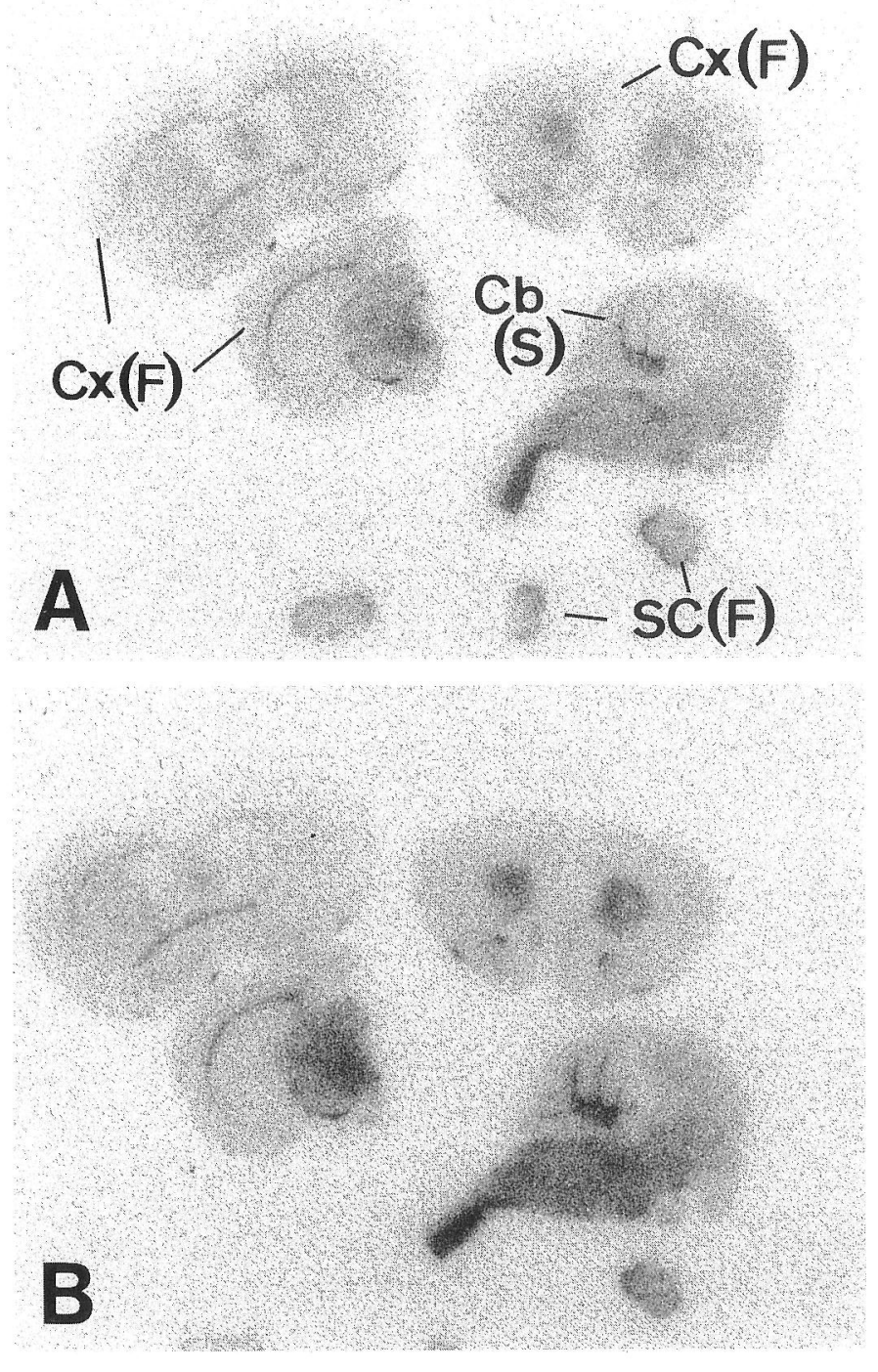

FIGS. 2. A-B. The effect of prehybridization on in situ hybridization. The effect of prehybridization was tested on paraffin sections prepared from the 18-day-old mouse brains. The sections with prehybridization (A) or without prehybridization (B) were hybridized with a ${ }^{32} \mathrm{P}-\mathrm{MBP}$ cDNA probe and exposed to X-ray film. For abbreviation keys, see the legend to Fig. 1. 
thermore, the treatment seemed to reduced the signal/noise ratio in the paraffin sections.

We next examined the effect of prehybridization on hybridization signals for MBP mRNA in paraffin sections. As shown in Figure 2, there was no obvious effect. The effect of the washing temperatures after hybridization was also examined in paraffin sections. The intensity of the hybridization signals and the signal/noise ratio were not significantly different among the three temperatures, 37,42 and $50^{\circ} \mathrm{C}$ (Fig. 3). However, there was a diffusion of signals when the sections were washed at $50^{\circ} \mathrm{C}$ (Fig. 3, arrows). From these results, we concluded that the proteinase digestion and prehybridization steps could be omitted from the in situ hybridization procedure when paraffin sections were used and that a suitable temperature for posthybridization washing was $37-42^{\circ} \mathrm{C}$. This relatively simple method was used to detect MBP and PLP mRNAs in paraffin sections from 30-day-old mouse brain. The distribution of MBP was demonstrated immunohistochemically and shown in Figure 4A. When in situ hybridization with ${ }^{35} \mathrm{~S}$-labeled MBP $\mathrm{cDNA}$ probe was performed on a section adjacent to that shown in Figure 4A, the distribution of MBP mRNA was found to be similar to that of MBP (Fig. 4B). In contrast to the diffuse distribution of signals for MBP mRNA in the white matter, signals for PLP mRNA formed small clusters throughout the white matter (Fig. 4C). At higher magnification, these autoradiograms revealed that MBP mRNA was located along nerve tracts whereas PLP mRNA was distributed preferentially in oligodendrocyte cell bodies (Fig. 5).

\section{DISCUSSION}

Our final goal in the present study was to succeed in situ hybridization for MBP and PLP mRNA in paraffin sections. Frozen sections have been the most widely used for in situ hybridization, although paraffin sections have also been used often. Recently, the successful application of in situ hybridization in tissue embedded in plastic (14) and in polyethylene glycol (1) have also been reported. Among these procedures of tissue preparation, we have chosen the paraffin embedding method because of the better retention of tissue architecture in paraffin sections and the easy acceptability of this method as routine work. We have found in this study a further advantage of paraffin sections in in situ hybridization, that is, the quality of tissues embedded in paraffin persists during long storage at room temperature. Paraffin sections prepared from a single tissue specimen have been used in several experiments over a period of one year. There was no degradation or diffusion of mRNAs during that time.

Hybridization of a nucleotide probe with a target sequence in tissue is performed essentially in accordance with filter hybridization. However, some pretreatment of

Figs. 3. A-C. The effect of the temperature of washing after hybridization on in situ hybridization. Paraffin sections prepared from the 18-day-old mouse brain were hybridized with a ${ }^{32} \mathrm{P}-$ labeled MBP cDNA probe. After the hybridization, the sections were washed at $37^{\circ} \mathrm{C}(\mathrm{A}), 42^{\circ} \mathrm{C}(\mathrm{B})$ or $50^{\circ} \mathrm{C}(\mathrm{C})$, and exposed to $\mathrm{X}$-ray film. Note the diffusion of signals at $50^{\circ} \mathrm{C}(\mathrm{C}$, arrows).

FIgs. 4. A-C. Immunohistochemistry for MBP (A), and in situ hybridization for MBP mRNA (B) and PLP mRNA (G) in parasagittal sections prepared from the 30-day-old mouse brain embedded in paraffin. In situ hybridization was performed using ${ }^{35} \mathrm{~S}-$ labeled MBP cDNA or PLP cDNA probes. Autoradiograms were obtained using Kodak NTB-2 emulsion and observed in a dark field. OB: olfactory bulb, Cx: cerebral cortex, Cb: cerebellum. Bar $=2 \mathrm{~mm}$. 


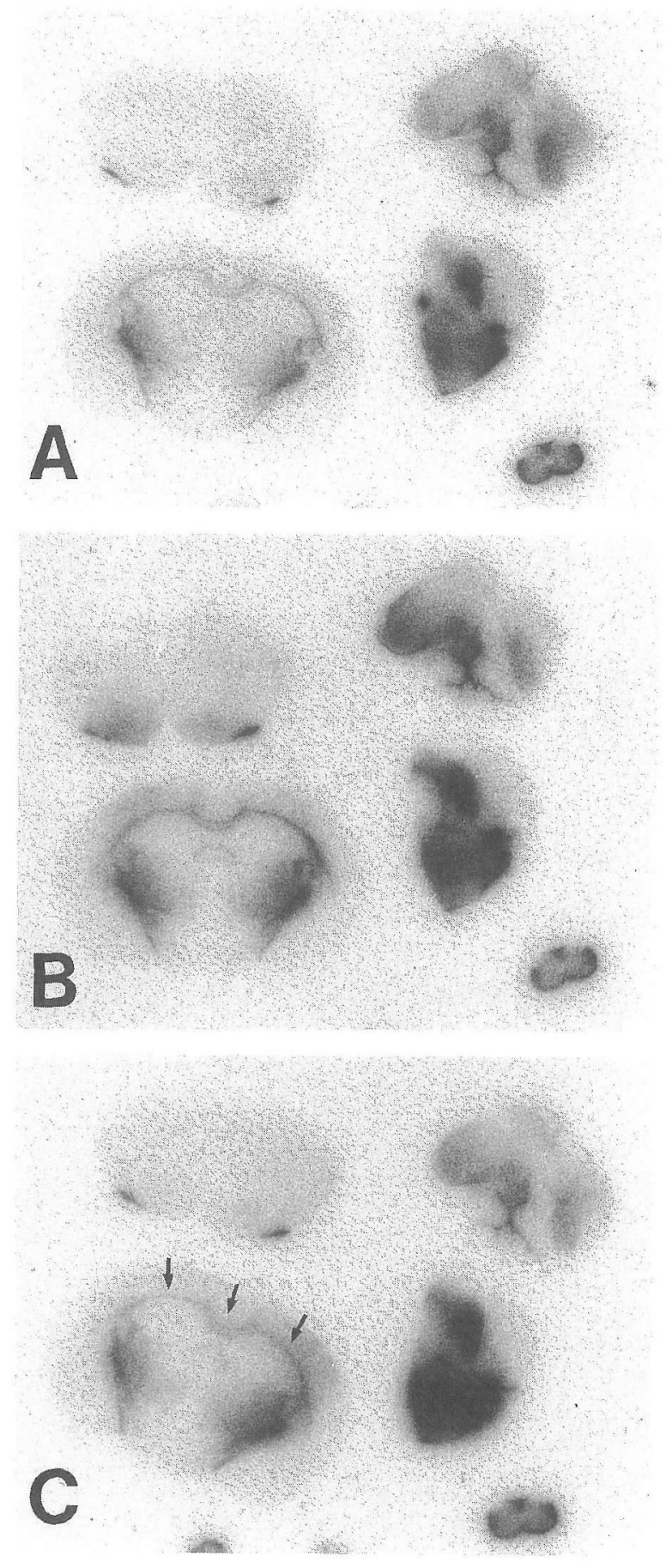



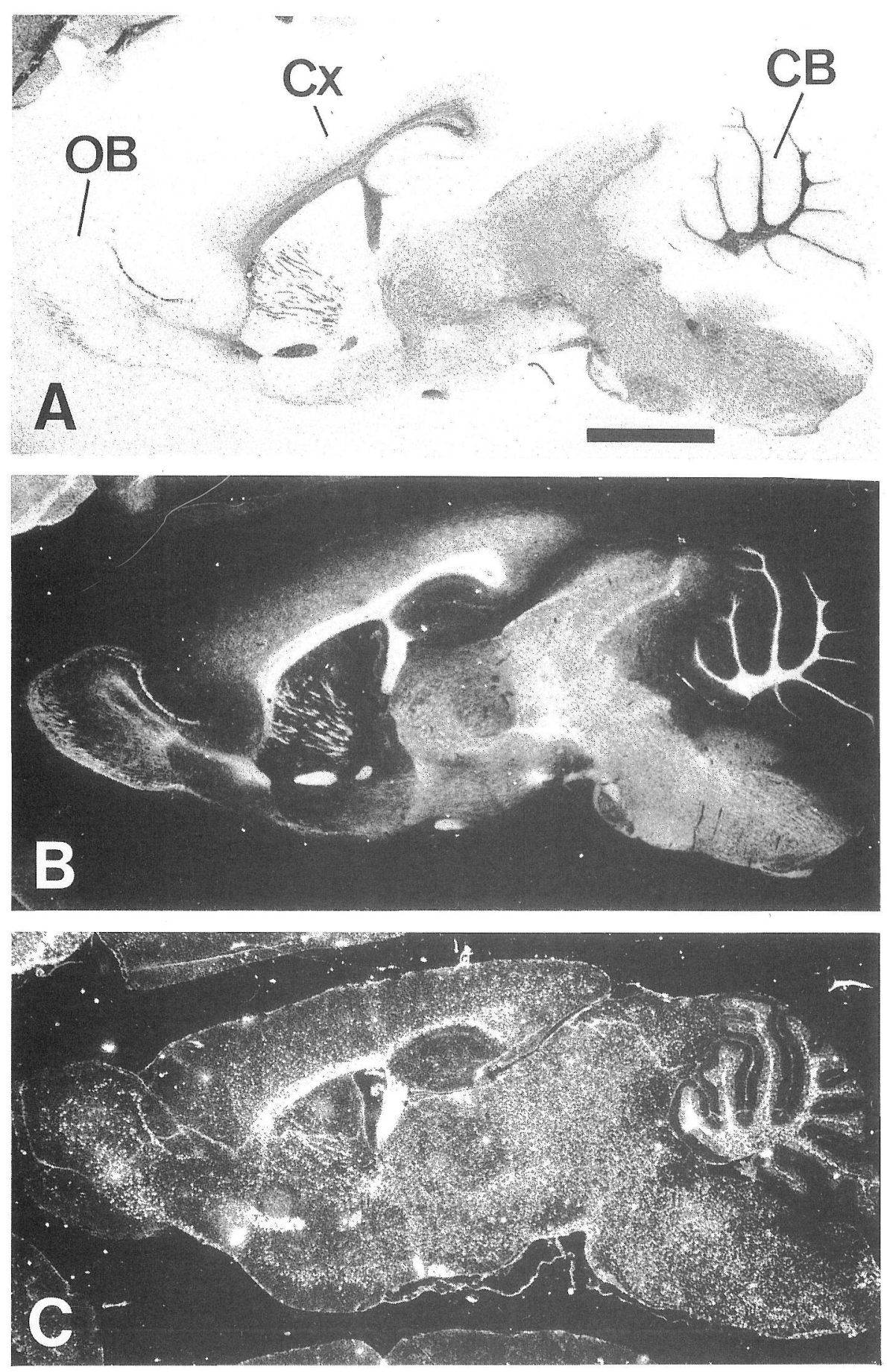
the sections, such as incubation in $\mathrm{HCl}$ solution and proteinase digestion, is necessary to facilitate the probe's penetration into the tissue. For this, proteinase digestion is thought to be the most efficacious. In fact, the intensity of hybridization signals in frozen sections was increased by proteinse $\mathrm{K}$ treatment. However, we found that
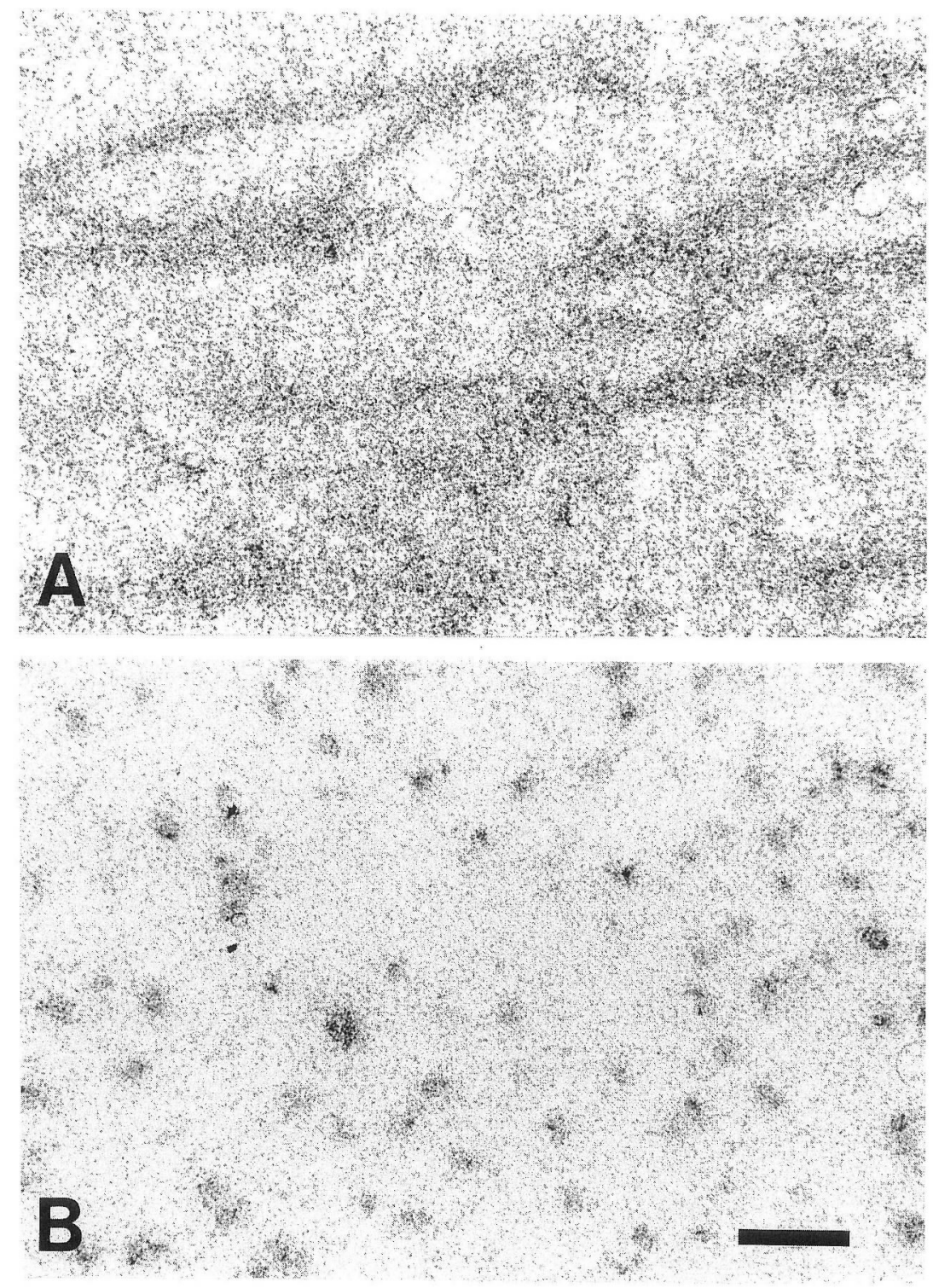

Figs. 5. A-B. Details of labeling with ${ }^{35}$ S-labeled MBP and PLP cDNA probes in the medulla oblongata from the 30-day-old mouse shown at higher magnification in a bright field. MBP mRNA is located along nerve tracts (A), whereas PLP mRNA is located in cell bodies (B). $\mathrm{Bar}=50 \mu \mathrm{m}$ 
hybridization occurred sufficiently in paraffin sections without this treatment. The procedure of embedding tissue in paraffin includes the treatment of the tissue with clearing agents. Furthermore, paraffin sections are treated with xylene to deparaffin them before use. The probe's penetration into paraffin sections is probably facilitated by the removal of lipids from the tissue during tissue processing.

We localized MBP and PLP mRNAs in mouse brain sections using the relatively simple method of in situ hybridization in which the proteinase $\mathrm{K}$ treatment and prehybridization were omitted. This method reveals the differential intracellular distribution of MBP and PLP mRNAs in oligodendrocytes; the MBP mRNA is distributed in the cell processes, whereas the PLP mRNA is located in the cell body. The details of the in situ hybridization study of the expression of MBP and PLP mRNAs has been described elsewhere (12).

\section{ACKNOWLEDGEMENTS}

This study was supported by a grant from the Japanese Ministry of Education, Science and Culture.

\section{REFERENCES}

1. Clayton, D. F. and Alvarez-Buylla, A.: In situ hybridization using PEG-embedded tissue and riboprobes: increased cellular detail coupled with high sensitivity. J. Histochem. Cytochem. 37; 389-393, 1989.

2. Gall, J. G. and Pardue, M. L.: Formation and detection of RNA-DNA hybrid molecules in cytological preparations. Proc. Natl. Acad. Sci. USA 63; 378-383, 1969.

3. Gall, J. G. and Pardue, M. L.: Nucleic acid hybridization in cytological preparations. Methods Enzymol. 38; 470-480, 1971.

4. Hafen, E., Levine, M., Garber, R. L. and Gehring, V. J.: An improved in situ hybridization method for the detection of cellular RNAs in Drosophila tissue sections and its application for localizing transcripts of the homeotic Antennapedia gene complex. EMBO J. 2; 617-623, 1983.

5. Harrison, P. R., Conkie, D., Paul, J., and Jones, K. W.: Localization of cellular globin messenger RNA by in situ hybridization to complementary DNA. FEBS Lett. 32; 109-112, 1973.

6. John, H. L., Birnsteil, M. L. and Hones, K. W.: RNA-DNA hybrids at the cytological level. Nature 223; 582-587, 1969.

7. Jordan, C., Friedrich, V. Jr, and Dubois-Dalcq, M.: In situ hybridization analysis of myelin gene transcripts in developing mouse spinal cord. J. Neurosci 9; 248-257, 1989.

8. Kimura, M., Inoko, H., Katsuki, M., Ando, A., Sato, T., Hirose, T., Takashima, H., Inayama, S., Okano, H., Takamatsu, K., Mikoshiba, K., Tsukada, Y. and Watanabe, I.: Molecular genetic analysis of myelin-deficient mice: Shiverer mutant mice show deletion in gene(s) coding for myelin basic protein. J. Neurochem. 44; 692-696, 1985.

9. Mikoshiba, K., Kohsaka, S., Takamatsu, K. and Tsukada, Y.: Neurochemical and morphological studies on the myelin of peripheral nervous system from shiverer mutant mice: absence of basic proteins common to central nervous system. Brain Res. 204; 455-460, 1981.

10. Mikoshiba, K., Takamatsu, K. and Tsukada, Y.: Peripheral nervous system of shiverer mutant mice: developmental change of myelin components and immunohistochemical demonstration of the absence of MBP and presence of $\mathrm{P} 2$ protein. Dev. Brain Res. 7; 71-79, 1983.

11. Milner, R. J., Lai, C., Nave, K.-A., Lenoir, D., Ogata, J. and Sutcliffe, J. G.: Nucleotide sequence of two mRNAs for rat brain myelin proteolipid protein. Cell 42; 931-939, 1985. 
12. Shiota, C., Miura, M. and Mikoshiba, K.: Developmental profile and differential localization of mRNAs of myelin proteins (MBP and PLP) in oligodendrocytes in the brain and in culture. Dev. Brain Res. 45; 83-94, 1989.

13. Trapp, B. D., Moench, T., Pulley, M., Barbosal, E., Tennekoon, G., and Griffic, J.: Spatial segregation of mRNA encoding myelin-specific protein. Proc. Natl. Acad. Sci. USA 84; 77737777, 1987.

14. Wide, M., Persson, H., Gunnarsson, S., Wide, L., and Seifi, L.: High frequency of in situ hybridization on thin plastic sections of human placenta with a cDNA probe for hCG. $J$. Histochem. Cytochem. 37; 1193-1196, 1989. 